\title{
Geometry Construction Problems in Electronic Educational Environment as a Development Means for the Students' Conceptual Mental Structure: Socio- Cultural Approach
}

\section{Problemas de construcción de geometría en el entorno educativo electrónico como medio de desarrollo de la estructura mental conceptual de los estudiantes: Enfoque Socio-Cultural}

Natalia Georgievna Podaeva

Bunin Yelets State University, Yelets, Russia

ORCID: https://orcid.org/0000-0002-9491-5011

Pavel Alexandrovich Agafonov

SBEI Secondary School No. 2070, Moscow, Russia

ORCID: https://orcid.org/0000-0002-8934-0233

Received 06-12-20 Revised 07-25-20 Accepted 08-20-20 On line 09-22-20

*Correspondence

Email: podaevan@bk.ru
Cite as:
Podaeva, N. G., \& Agafonov, P. A. (2020). Geometry Construction Problems in Electronic Educational Environment as a Development Means for the Students' Conceptual Mental Structure: Socio-Cultural Approach. Propósitos y Representaciones, 8 (SPE3), e712. Doi: http://dx.doi.org/10.20511/pyr2020.v8nSPE3.712 


\section{Summary}

In the context of the sociocultural approach, the authors studied the problem of the development of the students' conceptual mental structures in the process of geometry teaching. An educational activity for the development of a generalized ability to solve geometry construction problems in electronic educational environment served as a development means. The objective of the research is to introduce a characteristic of the technology for the formation of the students' generalized ability to solve geometry construction problems in electronic educational environment focusing on the development of conceptual mental structures. The key factor is the transition from the content-based mathematics teaching to instrument and value-based one, which corresponds to the transformation of the content sphere of mathematical knowledge into procedural and contextual. Construction problems introduce fundamentally new for an adolescent form of activity. This kind of work makes it possible to transform declarative knowledge that provides an understanding of educational material into procedural, providing mastering and application of geometric concepts. In addition, value-based knowledge is developed, providing the value positions experience and creating conditions for the formation of the axiological sphere of the student's personality. The statistical data analysis confirmed the hypothesis that the student's general proficiency in solving geometry construction problems in terms of socio-culturally oriented education influences positively the development of conceptual mental structures.

Keywords: Instrument-Based Education; Content-Based Education; Value-Based Education; Semantic Structures; Axiological Sphere of Personality.

\section{Resumen}

En el contexto del enfoque sociocultural, los autores estudiaron el problema del desarrollo de las estructuras mentales conceptuales de los estudiantes en el proceso de enseñanza de la geometría. Una actividad educativa para el desarrollo de una capacidad generalizada de resolver problemas de construcción de geometría en el entorno educativo electrónico sirvió como medio de desarrollo. El objetivo de la investigación es introducir una característica de la tecnología para la formación de la capacidad generalizada de los estudiantes para resolver problemas de construcción de geometría en el entorno educativo electrónico centrándose en el desarrollo de las estructuras mentales conceptuales. El factor clave es la transición de la enseñanza de las matemáticas basada en el contenido a la basada en instrumentos y valores, lo que corresponde a la transformación de la esfera de contenido del conocimiento matemático en procesal y contextual. Los problemas de construcción introducen una forma de actividad fundamentalmente nueva para un adolescente. Este tipo de trabajo permite transformar el conocimiento declarativo que proporciona una comprensión del material educativo en procedimental, proporcionando el dominio y la aplicación de los conceptos geométricos. Además, se desarrolla el conocimiento basado en valores, proporcionando la experiencia de posiciones de valor y creando condiciones para la formación de la esfera axiológica de la personalidad del estudiante. El análisis de los datos estadísticos confirmó la hipótesis de que la competencia general del estudiante para resolver los problemas de construcción de la geometría en términos de una educación de orientación sociocultural influye positivamente en el desarrollo de las estructuras mentales conceptuales.

Palabra clave: Educación basada en instrumentos; educación basada en contenidos; educación basada en valores; estructuras semánticas; esfera axiológica de la personalidad.

\section{Introduction}

The relevance of the study is determined by the fact that within the framework of psychodidactic paradigm the content of the subject should be based rather on the laws of the 
intellectual development of a person than on the normative scientific knowledge. Moreover, in terms of the sociocultural approach, socialization is regarded as the process of mastering the structural components of activity by the subject, including such forms as conceptual thinking. In this regard, the development of conceptual mental structures, providing the development of means of understanding and application of scientific concepts, value recognition, and understanding of the symbolic structures of disciplinary knowledge, should be considered as the main result of geometry teaching (Pasani, 2019).

The authors of the study assert the idea that in modern education the sociocultural function of teaching requires the development of conceptual mental structures of students as integral cognitive structures. These structures carry the conceptual knowledge and comprize various methods of information coding, as well as cognitive schemes of different degrees of generalization. Additionally, the concept is determined by the hierarchical organization of the semantic features and the correlation of individual concepts with the number of other concepts.

It has been discovered that the most relevant model for the development of conceptual mental structures in geometry teaching at school is an integral model, which components are introduced as the following blocks:

1) formation of cognitive schemes and semantic structures, i.e., reflexive attitude, which involves the student's understanding of mathematical information;

2) development of individual styles of information coding;

3 ) formation of the axiological sphere of the student's personality.

The presented classification is based on the differentiation of teaching types, areas of mathematical knowledge, as well as the types of scientific knowledge (Table 1).

Table 1.

Classification Based on the Differentiation of Teaching Types, Areas of Mathematical Knowledge, and the Types of Scientific Knowledge

\begin{tabular}{ccc}
\hline & Types of Mathematics Teaching & \\
\hline Content-based teaching & Instrument-based teaching & Value-based teaching \\
\hline & Spheres of Mathematics Knowledge & \\
\hline Content & Procedural & Contextual \\
\hline & Types of Scientific Knowledge & \\
\hline $\begin{array}{c}\text { Declarative (knowledge of } \\
\text { "What") }\end{array}$ & $\begin{array}{c}\text { Procedural (knowledge of } \\
\text { "How") }\end{array}$ & $\begin{array}{c}\text { Value (knowledge of "Which" } \\
\text { and "Why") }\end{array}$ \\
\hline
\end{tabular}

The main goal of declarative knowledge is to provide with understanding, i.e., the development of cognitive schemes, semantic structures of an individual system of the mathematics definitions' concept (Ushakova, 1970).

The main idea of the study is that the process of the concepts formation should include rather procedural and value knowledge than declarative ones. From this point of view, the main concern is the formation of the axiological sphere of personality as a socially determined orientation, which comprises cognitive, emotional and behavioral components. Value conception accounts for the cognitive component. The emotional component is presented by value relations that ensure the inclusion of value conception in a personally recognized system of values. This acceptance of value contributes to the formation of value orientations and personal meanings, which are included into the behavioral component presented by the realization of the values accepted by the students. In this regard, the construction problems serve as a fundamental form of activity for adolescents providing the formation of procedural and value knowledge. 
The analysis of various approaches to the definition of conceptual structures convinced the authors to apply the most relevant concept, according to which the conceptual thought is the result of an interchange of experience modalities, such as: verbal-communicational, visualspatial, subject-practical, and sensory-emotional (Wecker, 1976; Gelfman \& Kholodnaya, 2019; Kholodnaya, 2002; Ushakova, 1970). In these conditions, the main stages of the formation of the "subjective image of the concept" are motivation, categorization, enrichment, transfer and surrogation (Ushakova, 1970).

According to the analysis of the school methodology for mathematics teaching, it has been determined that traditionally, in terms of new concepts introduction, a lot of time is devoted to declarative knowledge, namely: mathematical objects and definitions (Wecker, 1976). Additionally, conceptual thinking, which is directly related to the development of thought actions and operations, should contribute to the transformation of declarative knowledge into procedural and value ones. In the process of construction problems teaching, students master graphical schemes, and improve the ability to match them to existing geometric objects, as well as develop sensor systems. In other words, there is a process of "transforming certain units of objectively existing knowledge into subjective mental structures that already exist "inside" a person's experience as new mental formations" (Wecker, 1976).

It has been discovered that there is still no general idea of the phenomenon of "geometric construction skill". Traditionally, it is regarded as educational skill based on substantive actions. The authors introduce the idea that this skill is based on real, formal and integral operations, which are internalized and inaccessible to objectification. Obviously, it is necessary to develop a unified, scientifically proven idea on the role of construction problems in formation of the adolescent's ability to establish the maximum number of symbolic connections in the surrounding and in development of conceptual mental structures.

There is no need to mention all the barriers that an educator faces in the context of the construction problems teaching at school. It is only worth highlighting, that many of them are caused by the absence of value relations, value orientations, and personal meanings.

\section{Literature Review}

The analysis of the education based on sociocultural approach, contributed to the identification of a number of trends, such as:

- teaching is considered as a sociocultural phenomenon (Sorokin, 1992; Slepkan, 1983);

- social values are important social factors (Shchedrovitsky, 1995; Shershov, 1980);

- the concept of the sociocultural function of education is considered as the regulation of the relations between an individual and social experience through certain mechanisms, which include value orientations and a value approach (Shershov, 1980).

It is worth highlighting the concept of socio-cultural teaching of mathematics in terms of the analysis of the concepts and ideas introducing special understanding of the public knowledge perception by an individual (Podaeva et al., 2019a, 2019b; Podaeva \& Podaev, 2014, 2016). The presented approach provides the idea that in modern education, the recognition of the sociocultural function of teaching presupposes the existence of sociocultural technology, which tends to transfer socially and personally significant experience, formed as knowledge, skills, competencies and basic cultural abilities.

The most important properties of conceptual thinking were fundamentally developed in science (Wecker, 1976; Vygotsky, 1982; Vladimirtseva, 2007; Halperin, 1985; Davydov, 1992; Kabanova-Meller, 1962; Piaget, 1969; Metelsky, 1982; Rubinstein, 1999; Podaeva \& Podaev, 2016; Kholodnaya, 2002; Ushakova, 1970). The process of mathematical concepts mastering by 
schoolchildren was studied in the works of Grudenov (1987), Gusev (2003), Dalinger (2006), Metelsky (1982), Poincaré and Hadamard (1949), Sarantsev (1999), Slepkan (1983), Ustilovskaya (2008), Yakimanskaya (2004) and others. Podaeva, Podaev, and Agafonov in their research highlighted the components of a integral mental structure that provides the formation of geometric concepts in the context of geometry teaching (Podaeva et al., 2019a, 2019b; Podaeva \& Podaev, 2014, 2016).

Kaivo-oja, Tsirel, and Zieberman devoted their works to the problem of introducing automation into the educational environment (Kaivo-oja \& Roth, 2015). Digitalization of teaching and the transformation of the role of a teacher in education in the context comprehensive digitalization of the educational process was studied in works by Kupriyanovsky et al. (2016), Namiot et al. (2017), Bruce and Chiu (2015), Dicheva et al. (2015), Fenwick and Edwards (2016), Instefjord (2015), Lai and Hong (2015), Nielsen et al. (2015), Tømte et al. (2015).

Golitsyna (2014) studied the use of digital environment in the educational process. Modular digital educational environments were analyzed in the works by Watson et al. (2015), Wilcox (2015). Massive Open Online Courses (MOOC) and distance education were investigated in the research by Kupriyanovsky et al. (2016), Lebedeva (2015), Makoveichuk (2015), Valeeva and Rudneva (2016), Klassov and Klassova (2016), Gharawi et al. (2020).

\section{Methods}

The purpose of experimental teaching was to develop conceptual mental structures for grades 8 to 9 through the mastering of generalized skills in solving geometry constructions problems within the framework of the elective course "Constructive geometry on the Euclidean plane".

According to the experimental methodology, the actions that form the essence of the ability to solve constructive problems were regarded as a special subject of learning. The units of thinking were presented by integral operations that were fixed in the mind as images, and comprised real and formal operations, providing the cohesion of the subject plane (the plane of the geometric object) and the sign plane. The authors introduced an example of a particular lesson in the framework of the experimental elective course for the 9th grade. The theme of the lesson was "The intersection method for solving construction problems using a compass and a ruler. Apollonius circles."

Firstly, the concept of the intersection method was revealed. The problem was reduced to the construction of one point $X$, i.e., the basic element of the construction, which satisfied any two conditions $\alpha_{1}$ and $\alpha_{2}$ following the statement of the problem:

"Let $F_{1}$ be the set (geometrical locus) of points satisfying the condition $\alpha_{1}$, and $F_{2}$ be the set (geometrical locus) of points satisfying the condition $\alpha_{2}$. Then the desired point $X$ is any point in the set $F_{1} \cap F_{2}$."

The images (geometric loci of points) of $F_{1}$ and $F_{2}$ were analyzed by means of GeoGebra dynamic software.

Next, we consider the support problem: "Let there be given a segment $A B$ and a point $C$, which belongs to the line $A B$. It is necessary to construct a geometric locus of points $F=$ $\{X \mid A X: X B=A C: C B\}$ (Apollonius circle)."

Formal deductive reasoning was preceded by a mathematical experiment in GeoGebra system. After analyzing the condition, at the stage of analysis, an assumption was made that the problem had been solved, i.e., $X$ is one of the points of the desired set $\boldsymbol{F}$. Therefore, $X C$ was the 
bisector of the angle $A X B$. We considered such a point $\boldsymbol{D}$ on line $A B$ that line $X \boldsymbol{D}$ was perpendicular to $\boldsymbol{X C}$. It has been concluded that $\boldsymbol{X D}$ is the bisector of the angle exterior to $A X B$. Therefore, $\angle \boldsymbol{C X} \boldsymbol{D}=\mathbf{9 0}^{\circ}$ and the point $X$ lay on a circle with diameter $\boldsymbol{C D}$. Then, inverse arguments were carried out and it was proven that any point of a circle with diameter $C D$ belonged to the set $\boldsymbol{F}$. It was concluded that the set $F$ was a circle, which is called the circle of Apollonius. Further discussion was based on the bottom-up method. It means that to construct the circle of Apollonius, it is enough to find the point $D$ and draw a circle with a diameter of $C D$. The students wondered how to build point $\boldsymbol{D}$. The answer was provided by the Thales's theorem (Figure 1).

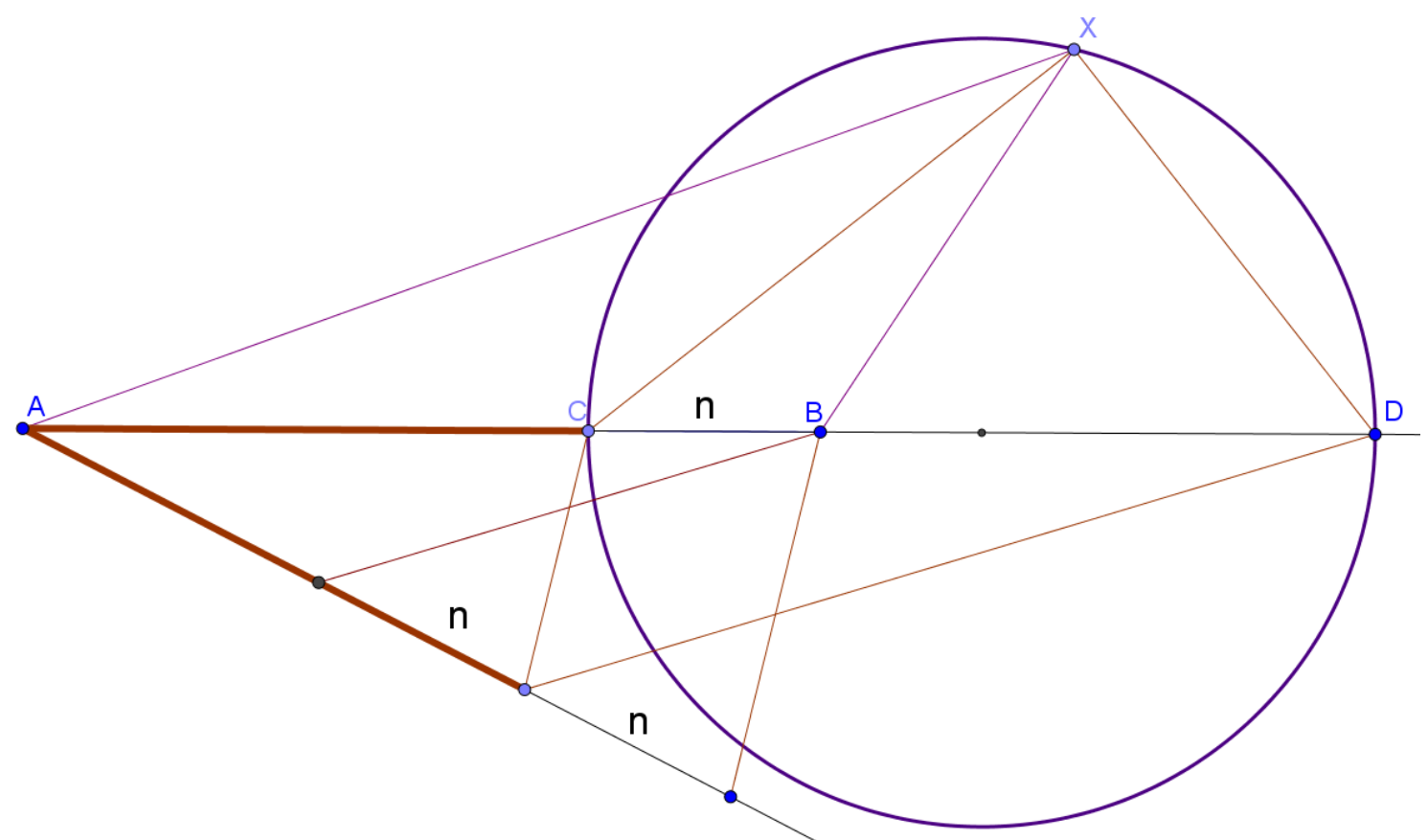

Figure 1. The answer provided by the Thales's theorem

This method allowed to define the concept of "Apollonius circle". In this context, the Apollonius circle was considered as an image fixing a mathematical object, its connections and relations. Mastering of this aspect through simple memorization is impossible.

\section{Results}

Experimental testing was carried out on the base of SBEI Moscow Secondary School №2070 of KSD (Kommunarsk School Division) and SBEI Moscow Secondary School №2070 of BSD (Buninsk School Department) from 2017 to 2020. The participants of the experiment identified prespecified classes (specialization in physics and mathematics):

- 8 "a" and 9 "a" forms of SBEI Moscow Secondary School No. 2070 of KSD (Kommunarsk School Division) -;

- $\quad 8$ "c" and 9 "c" forms of SBEI Moscow Secondary School No. 2070 of BSD (Buninskoye School Division).

The elective course "Constructive geometry on the Euclidean plane" was an additional optional form of subject training and an important mechanism supporting the basic program in geometry.

In the framework of evaluation analysis of the results of an experimental study, the authors involved independent characteristics for the actions being formed, such as: systematics, reflexivity, reversibility, flexibility, form of action, degree of generalization and categorization, 
measure of deployment, measure of transfer, measure of development and enrichment, axiological sphere, measure of surrogation.

The authors of the present study introduced Table 2 for a comparative analysis of a generalized way of solving geometry construction problems in electronic educational environment and for assessing the development level of the students' conceptual mental structures.

Table 2.

Comparative Analysis of a Generalized Way of Solving Geometry Construction Problems in Electronic Educational Environment and for Assessing the Development Level of the Students' Conceptual Mental Structures

\begin{tabular}{|c|c|c|c|}
\hline № & Level & $\begin{array}{c}\text { Psychodidactic } \\
\text { Patterns }\end{array}$ & Characteristics of the Development Criterion \\
\hline 1. & Understanding & $\begin{array}{c}\text { Awareness, } \\
\text { generalization, } \\
\text { comprehension }\end{array}$ & $\begin{array}{c}\text { Reflexive criterion: } \\
\text { - knowledge is declarative; } \\
\text { - ability to solve problems is generalized, but } \\
\text { not characterized by the quickness of execution } \\
\text { of actions; } \\
\text { - the constructions are based on the analysis } \\
\text { results, but are poorly reasoned. } \\
\text { Cognitive criterion: value positions are } \\
\text { perceived, but not accepted by the student's } \\
\text { personality. } \\
\text { Emotional criterion: value attitude is not } \\
\text { developed. } \\
\text { Behavioral criterion: } \\
\text { value orientations are limited; } \\
\text { - } \quad \text { personal meanings are not developed; } \\
\text { extended cognitive motives prevail; } \\
\text { internal motives are subordinate to } \\
\text { - external ones. }\end{array}$ \\
\hline 2. & Learning & $\begin{array}{l}\text { Remembering, } \\
\text { systematization, } \\
\text { prevention of } \\
\text { forgetting }\end{array}$ & $\begin{array}{c}\text { Reflexive criterion: } \\
\text { knowledge is declarative; } \\
-\quad \text { thinking ability is automated; } \\
\text { students prove their point of view. } \\
\text { Cognitive criterion: value positions are } \\
\text { accepted by the student's personality. } \\
\text { Emotional criterion: value attitude is at the } \\
\text { formation stage. } \\
\text { Behavioral criterion: } \\
\text {-the transformation of broad cognitive motives } \\
\text { into educational and cognitive ones; } \\
\text {-internal and external motives are balanced. } \\
\text { Reflexive criterion: }\end{array}$ \\
\hline 3. & $\begin{array}{l}\text { Emotionally } \\
\text { evaluative }\end{array}$ & $\begin{array}{l}\text { The experience } \\
\text { of value } \\
\text { positions }\end{array}$ & $\begin{array}{l}\text { Reflexive criterion: } \\
\text { students' knowledge is value-based, } \\
\text { expressed in the form of value judgments; } \\
\text { reliance on sensory and emotional way } \\
\text { of information coding. } \\
\text { Cognitive criterion: value positions are } \\
\text { included into the student's personally accepted } \\
\text { value system. } \\
\text { Emotional criterion: value relationships are } \\
\text { developed. }\end{array}$ \\
\hline
\end{tabular}




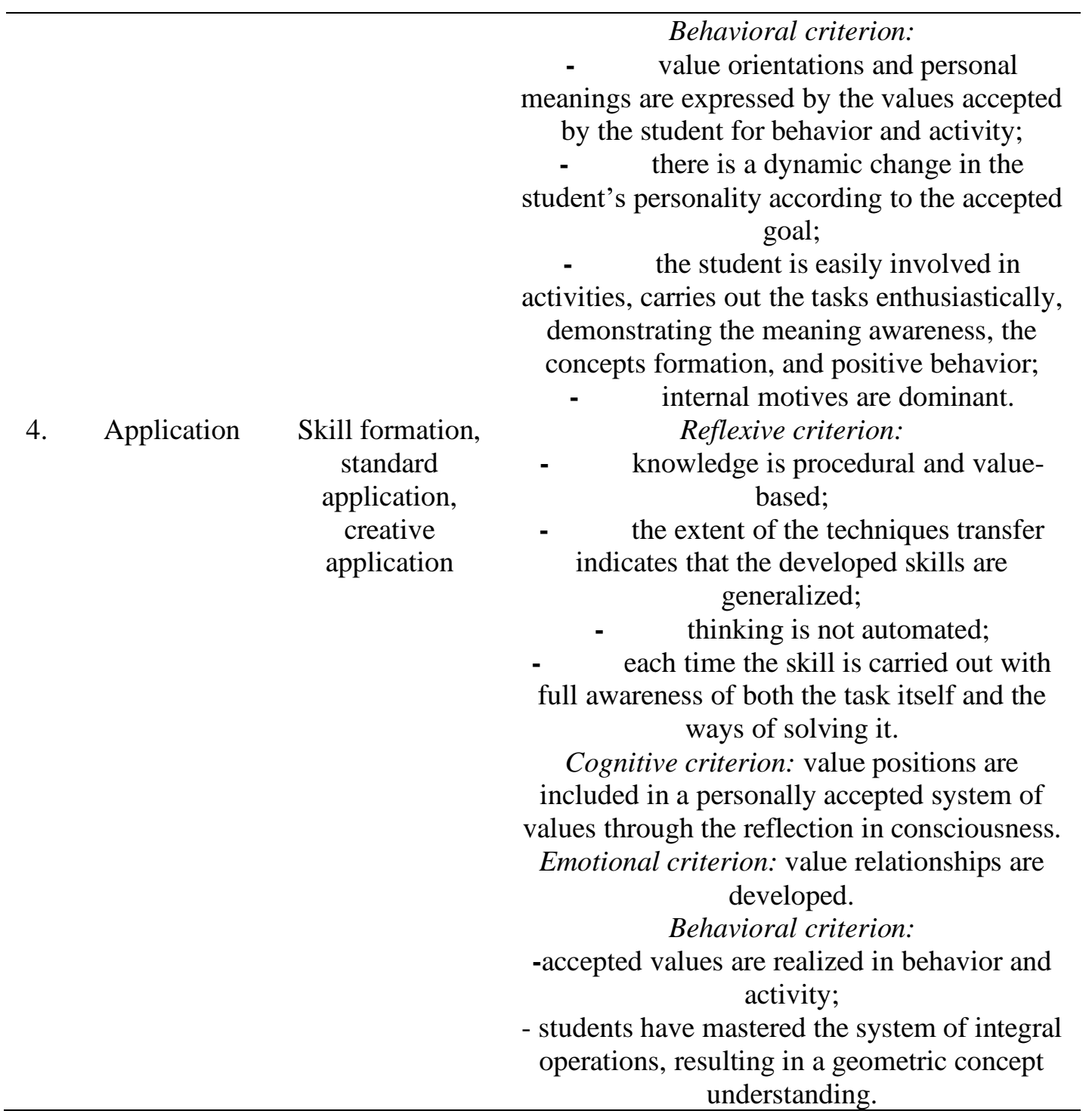

The results of the statistical data analysis confirmed the hypothesis of a significant influence of the level of mathematical training (significance level $p=0.003$ ) in combination with the experimental teaching methods (significance level $\mathrm{p}=0.001$ ) and the duration of training by means of experimental methods (significance level $\mathrm{p}=0.02$ ). Additionally, there have been discovered the correlation between the level of formation of conceptual mental structures and the level of significance, depending on the factors studied.

\section{Conclusion}

The presented formative experiment, the analysis and statistical processing of its results contributed to the conclusion, confirming the research hypothesis, i.e., the level of geometry learning is dynamically developing, namely, such an indicator of the personal intellectual development as conceptual mental structures. In this context, the education based on sociocultural approach within the framework of the elective course "Constructive geometry on the Euclidean plane" serves as an additional optional form of training and is a significant mechanism that supports the main program. Moreover, methodological support of this process is carried out according to the following provisions:

- the content of additional geometry training is based on the sociocultural concept of mathematical education; 
- the process of the development of conceptual mental structures is connected to the student's mastering of the generalized ability to solve geometry construction problems, which is greatly facilitated by the use of GeoGebra dynamic software, which can be regarded as electronic educational environment (EES);

- the specifics of the of geometry teaching is based on a integral model, which components are introduced as the following blocks:

1) formation of cognitive schemes and semantic structures, i.e., reflexive attitude, which involves the student's understanding of mathematical information;

2) development of individual styles of information coding;

3) formation of the axiological sphere of the student's personality.

\section{Acknowledgments}

The study was carried out with the financial support of The Russian Foundation for Basic Research (scientific project No. 19-313-90018 "Methodological support of the students' geometric knowledge development in the electronic educational environment"), provided in accordance to the results of the competitive selection for the best fundamental research carried out by postgraduate students ("The Postgraduates").

\section{References}

Bruce, D. L., \& Chiu, M. M. (2015). Composing with new technology: Teacher reflections on learning digital video. Journal of Teacher Education, 66(3), 272-287.

Dalinger, V. A. (2006). Methods of teaching the proof of mathematical sentences. Moscow: Prosveschenie.

Davydov, V. V. (1992). The psychological theory of educational activities and methods of elementary education, based on a meaningful generalization. Tomsk: Publishing House "Peleng".

Dicheva, D., Dichev, C., Agre, G., \& Angelova, G. (2015). Gamification in education: A systematic mapping study. Journal of Educational Technology \& Society, 18(3), 75-88.

Fenwick, T., \& Edwards, R. (2016). Exploring the impact of digital technologies on professional responsibilities and education. European Educational Research Journal, 15(1), 117-131.

Gelfman, E. G., \& Kholodnaya, M. A. (2019). Psychodidactics of a school textbook: training manual for university students (2nd Edit.). Moscow: Yurayt Publishing House.

Gharawi, M. A., Bidin, A., \& Choo, K. A. (2020). Malaysian learners' preferences-based profile model towards adaptive massive open online courses. Journal of Southwest Jiaotong University, 55(1). doi:10.35741/issn.0258-2724.55.1.51

Golitsyna, I. N. (2014). Technology Education 3.0 in the modern educational process. Educational Technologies and Society, 17(3), 646-656.

Grudenov, Ya. I. (1987). Psychological and didactic foundations of the mathematical teaching methodology. Moscow: Pedagogika.

Gusev, V. A. (2003). Psychological and pedagogical foundations of mathematics teaching. Moscow: Publishing House "Verbum-M", Publishing Center "Academy".

Halperin, P. Ya. (1985). Teaching methods and mental development. Moscow: Prosveschenie.

Instefjord, E. (2015). Appropriation of digital competence in teacher education. Nordic Journal of Digital Literacy, 10, 155-171.

Kabanova-Meller, E. N. (1962). Psychology of the students' knowledge and skills formation. Moscow: Publishing House of the APS of the RSFSR.

Kaivo-oja, J., \& Roth, S. (2015). The technological future of work and robotics. [http://hdl.handle.net/10419/118693] [Accessed on 4 March, 2020].

Kholodnaya, M. A. (2002). Psychology of intelligence: Paradoxes of the study. Saint Petersburg: Piter. 
Klassov, A. B., \& Klassova, O. V. (2016). The use of distance learning system in the educational process. Science Almanac, 3-2, 165-169.

Kupriyanovsky, V. P., Sinyagov, S. A., Namiot, D. E., Dobrynin, A. P., \& Chernykh, K. Yu. (2016). Information technology in the university system, science and innovation of the digital economy on the example of the UK. International Journal of Open Information Technologies, 4(4), 30-39.

Lai, K. W., \& Hong, K. S. (2015). Technology use and learning characteristics of students in higher education: Do generational differences exist? British Journal of Educational Technology, 46(4), 725-738.

Lebedeva, M. B. (2015). Massive open online courses as a trend in the development of education. Human and Society, 1(42), 105-108.

Makoveichuk, K. A. (2015). Prospects of using MOOC in basic educational programs of higher education in Russia. International Research Journal, 63, 66-67.

Metelsky, N. V. (1982). Didactics of mathematics. Minsk: Belarusian State University.

Namiot, D. E., Kupriyanovsky, V. P., Samorodov, A. V., Karasev, O. I., Zamolodchikov, D. G., \& Fedorova, N. O. (2017). Smart Cities and education in digital economy. International Journal of Open Information Technologies, 5(3), 56-71.

Nielsen, W., Miller, K. A., \& Hoban, G. (2015). Science teachers' response to the digital education revolution. Journal of Science Education and Technology, 24(4), 417-431.

Pasani, C. F. (2019). Analyzing elementary school students geometry comprehension based on Van Hiele's theory. Journal of Southwest Jiaotong University, 54(5). doi:10.35741/issn.0258-2724.54.5.31

Piaget, J. (1969). Selected psychological works. Psychology of intellect. Moscow: Prosveschenie.

Podaeva, N. G., \& Podaev, M. V. (2014). Updating the content of school mathematical education: Sociocultural approach. Saint Petersburg: Publishing House "Lan".

Podaeva, N. G., \& Podaev, M. V. (2016). Technology of sociocultural approach to geometry teaching of in a general education school. Yelets: Yelets State Ivan Bunin University.

Podaeva, N. G., Podaev, M. V., \& Agafonov, P. A. (2019a). Concepts formation in the process of geometry teaching for the schoolchildren in electronic educational environment. Concept, 6, 10-25.

Podaeva, N. G., Podaev, M. V., \& Agafonov, P. A. (2019b). The social and cultural approach to forming geometric concepts among schoolchildren. Amazonia Investiga, 8(20), 459467.

Poincaré, H., \& Hadamard, J. (1949). An essay on the psychology of invention in the mathematical field. Princeton, NJ: Princeton University Press.

Rubinstein, S. L. (1999). Fundamentals of general psychology. Saint Petersburg: Piter Kom.

Sarantsev, G. I. (1999). The objectives of mathematics teaching in secondary school in modern conditions. Mathematics in School, 6, 36-41.

Shchedrovitsky, G. P. (1995). Selected works. Moscow: School of Cultural Policy.

Shershov, I. E. (1980). Culture dynamics. Minsk: Belarusian State University.

Slepkan, Z. I. (1983). Psychological and pedagogical foundations of mathematics teaching. Study guide. Kiev: Radyanska shkola.

Sorokin, P. A. (1992). Human being, civilization, society. Moscow: Prosveschenie.

Tømte, C., Enochsson, A. B., Buskqvist, U., \& Kårstein, A. (2015). Educating online student teachers to master professional digital competence: The TPACK-framework goes online. Computers \& Education, 84, 26-35.

Ushakova, T. N. (1970). Functional structures of the second signaling system. Moscow: Nauka.

Ustilovskaya, A. A. (2008). Psychological mechanisms of overcoming of sign naturalization of the ideal content of geometrical concepts. Candidate Thesis, Moscow.

Valeeva, N. G., \& Rudneva, M. A. (2016). MOOC for teaching English to ecological faculty students. Bulletin of the Peoples' Friendship University of Russia. Series "Ecology and Life Safety", 3, 99-105.

Vladimirtseva, S. A. (2007). Theory and methodology of mathematics teaching: General methodology (2nd Edit.). Barnaul: Publishing House of BSPU. 
Vygotsky, L. S. (1982). Thinking and speech. Collected works in 6 volumes (Vol. 2). Moscow: Pedagogika.

Watson, W. R., Watson, S. L., \& Reigeluth, C. M. (2015). Education 3.0: Breaking the mold with technology. Interactive Learning Environments, 23(3), 332-343.

Wecker, L. M. (1976). Mental processes. Thinking and intelligence (Vol. 2). Leningrad: Publishing House of Leningrad State University.

Wilcox, C. (2015). The role of automation in undergraduate computer science education. Proceedings of the 46th ACM Technical Symposium on Computer Science Education, 90-95. doi:10.1145/2676723.2677226

Yakimanskaya, I. S. (2004). The psychological foundation of mathematical education: Training manual university students. Moscow: Academia. 